\title{
NUTRITIVE VALUE OF NAPIER GRASS(PENNISETUM PURPUREUM SCHUM.) SILAGE ENSILED WITH MOLASSES BY GOATS
}

\author{
H. Yokota ${ }^{1}$, T. Okajima and M. Ohshima \\ Department of Grassland Science, The Farm. \\ School of Agriculture, Nagoya University, Togo, Aichi 470-01, Japan
}

\begin{abstract}
Summary
Napier grass (Pennisetum purpureum Schum.) harvested at an early growth stage was ensiled with $4 \%$ of molasses in a polyethylene bag silo which contained $15 \mathrm{~kg}$ of chopped forage each. Dry matter (DM) content of the silage was so low as $14.75 \%$, although chemical quality of the silage was very high. Ratio of ammonia nitrogen to total nitrogen was $6.59 \%$, and the $\mathrm{pH}$ value of the silage was 3.79. Nutritive value of the silage was estimated using goats and compared to that of a timothy hay as a reference ration. Feeding level of each rations was adjusted to a level of initrogen $(\mathrm{N})$ recommendation. DM and $\mathrm{N}$ digestibilities of the silage were 65.0 and $54.5 \%$, respectively, but those of the timothy hay were 37.6 and $37.2 \%$. Feeding of the napier grass silage maintained body weight and kept positive $\mathrm{N}$ retention. Ammonia $\mathrm{N}$ concentration in the rumen fluid in goats fed the napier grass silage increased after feeding, but blood urea concentration was constant. Feeding of the timothy hay did not increase ammonia $\mathrm{N}$ concentration in the rumen fluid, but increased blood urea concentration. These facts indicated that the napier grass silage had enough digestible DM and $\mathrm{N}$ for maintenance ration to goats.
\end{abstract}

(Key Words : Napier Grass, Pennisetum purpureum Schum., Silage, Nutritive Value, Goat)

\section{Introduction}

Grasses in the tropics and subtropics grow rapidly during period of much precipitation and high temperature, and lead to mature grasses containing high levels of cell wall constituents. Napier grass (Pennisetum purpureum Schum.) is one of the popular grasses in the tropics and subtropics, and is usually harvested at short intervals to feed at an early growth stage, because the nutritive value of the grass depends on harvesting intervals (Woodard and Prine, 1991). Against the seasonal scarcity of feed for livestock in the area which has a long dry season, the grass should be stored. As pointed out by Brown and Chavalimu (1985) drying the grass is difficult because grasses grow in a season which has much precipitation. Another storage method is silage making. Yokota et al. (1991) reported that napier grass ensiled with molasses could be stored as a silage at a good condition even if the silages

\footnotetext{
${ }^{1}$ Address reprint requests to Dr. H. Yokota, Department of Grassland Science, The Farm, School of Agriculture, Nagoya University, Togo, Aichi 470-01, Japan.

Received August 31, 1991

Accepted November 25, 1991
}

were stored in a high ambient temperature.

In this experiment nutritive value of napier grass silage was estimated by feeding trial using goats and compared with that of a timothy (Phleum pratense L.) hay.

\section{Materials and Methods}

\section{Herbage}

Napier grass was transplanted at the first week of April, 1987 at our farm near Nagoya located in south coast of central Japan. The first growth was harvested on July 27, 1987 by hand mowers and used for the preparation of silages.

\section{Preparation of silage}

The forage was cut in a length of $3 \mathrm{~cm}$, and $15 \mathrm{~kg}$ of the chopped forage was mixed with $600 \mathrm{~g}$ of molasses by hands on a plastic sheet. The mixture was packed into a polyethylene bags $(625 \mathrm{~mm}$ in width, $800 \mathrm{~mm}$ in height and $0.06 \mathrm{~mm}$ in thickness). The upside of each bag was closed by tying with strings after removing air by a vacuum pump. The bags were kept in a dark room at ambient temperature (10 to 35 $\left.{ }^{\circ} \mathrm{C}\right)$ for 3 months until digestion trials. 


\section{Digestion trial}

Three castrated Shiba goats (Japanese pigmy goats, 11 months old) weighing about $11.6 \mathrm{~kg}$ were used. They were reared individually in metabolism cages during the trial. They were given the silage for 12 days and all the feces and urine were collected for the last 5 days. Urine was preserved under an acid condition of $\mathrm{H}_{2} \mathrm{SO}_{4}$. Aliquots of feces and urine were taken from the daily collection and composited as a 5-day pooled samples. To compare nutritive value of the silage, a commercial timothy hay was used as a reference ration. Following to the silage feeding trial, similar trial was made on the hay. Feeding levels were adjusted by the amount of nitrogen intake which was recommended by NRC; $2200 \mathrm{~g}$ of the fresh silage or $460 \mathrm{~g}$ of the hay $(86.2 \% \mathrm{DM})$ was given a day. Half of the ration was given at 8:00 and the other half at 17:00. One gram of $\mathrm{CaCO}_{3}$ was given with each ration. On the 4th day of the feces and urine collecting period, rumen fluid and blood samples were taken from each goat. Fifty $\mathrm{ml}$ of rumen fluid was sucked by stomach tube and $3 \mathrm{ml}$ of blood was taken from jugular vein just before and at 4 hours after the morning feeding. The rumen fluids were immediately filtered through double cheese cloth and added $\mathrm{HgCl}_{2}$ to stop further fermentation, and the blood plasma was taken by centrifuge. Both the rumen fluid and the blood plasma samples were stored at $-20^{\circ} \mathrm{C}$.

\section{Chemical analysis}

The dry matter (DM) contents of silage samples were determined by the toluene distillation method (Dewar and McDonald, 1961). Those of the hay sample were determined by oven-drying procedure at $135^{\circ} \mathrm{C}$ for 2 hours. Crude protein determination was made by the Kjeldahl method on fresh silages and dried powder of the hay. Nitrogen $(\mathrm{N})$ concentrations of feces and urine samples were also determined by the Kjeldahl method. Chemical quality of silages were determined on cold water extracts. The $\mathrm{pH}$ values of the rumen fluids and the silage juices were determined with a glass electrode $\mathrm{pH}$ meter (F-12, Horiba Co., Kyoto). The former was measured just after the filtration by cheese cloth. Lactic acid in silages was determined by the colorimetric method of Barnett (1951). Total VFA concentrations were analysed by steam distillation method and individual VFA was determined by a gas chromatography (GC-12A, Shimadzu Co. Ltd., Kyoto). Urea $\mathrm{N}$, total protein and glucose concentration in blood plasma were estimated using commercial kits (Chugai Pharmaceutical Ltd., Tokyo).

\section{Statistics}

The significance of difference between values for digestibilites of napier grass silage and those of timothy hay was examined by Student's $t$ test. Data for rumen fluids and blood samples were also analysed between rations as well as between sampling time.

\section{Results and Discussion}

The chemical quality of the napier grass silage is shown in table 1. In the previous experiment (Yokota et al., 1991) napier grass was harvested at an interval of about a month and ensiled with molasses and the DM contents of the silages which were made from June to October were 12.9 to $16.4 \%$. In this experiment DM content of the silage was $14.8 \%$. It is difficult to make napier grass silage which contains more than 20 $\%$ of DM, unless the grass is wilted. The $\mathrm{pH}$ value of the silage was 3.79 , which was lower than the mean value of 3.95 in the previous experiment. Woodard and Prine (1991) reported that the $\mathrm{pH}$ values of napier grass silage were 3.8 to 4.4 and depended on harvest frequency and genotype of the forage. Lactic acid was the main preservative organic acid in the silage and

TABLE 1. CHEMICAL QUALITY OF THE NAPIER GRASS SILAGE SUPPLEMENTED WITH $4 \%$ OF MOLASSES

\begin{tabular}{lcc}
\hline Dry matter & $\%$ & $14.75 \pm 0.66^{1{ }^{1}}$ \\
Crude protein & $\mathrm{g} / \mathrm{kg} \mathrm{FM}^{2)}$ & $13.50 \pm 0.15$ \\
pH & & $3.79 \pm 0.03$ \\
Total acids & DM \% & $16.52 \pm 2.42$ \\
Lactic acid & DM \% & $14.2 \pm 2.3$ \\
Acetic acid & DM \% & $2.34 \pm 0.61$ \\
Propionic acid & DM \% & $0.01 \pm 0.00$ \\
Butyric acid & DM \% & $0.02 \pm 0.01$ \\
Ammonia N/Total N & $\%$ & $6.59 \pm 0.54$ \\
\hline
\end{tabular}

1) Mean \pm standard error of the mean $(n=5)$.

2) Fresh matter. 
acetic acid was the next one. Butyric acid content was negligible. Several researchers (Catchpoole and Henzell, 1971; Panditharatne et al., 1986) suggested that acetic acid, rather than lactic acid, is the main preservative in tropical forage silage. They ensiled the forage in a large scale silo, but in this experiment a small polyethylene bag silo was used, and $4 \%$ of molasses was added as an additional WSC. The main preservative organic acid for silage may also depend on the extent of compression of forages in silo. Henderson and McDonald (1975) and Miller et al. (1961) showed delayed sealing resulted in a reduction in the amount of lactic acid produced and frequently a normally dominant lactic acid bacterial fermentation was replaced by a clostridial one. McDonald et al. (1991) cited that the silages were well-preserved and contained appreciable amounts of lactic acid at the low oxygen level in the silages. At the high oxygen level, however, the silages produced were of high $\mathrm{pH}$ value and lower amounts of lactic acid. Ratio of ammonia $\mathrm{N}$ to total $\mathrm{N}$ content was $6.59 \%$ and it should be said the silage was a good one.

The results of the feeding trials of the silage and the timothy hay are shown in table 2. As $\mathrm{DM}$ and $\mathrm{N}$ digestibilities of the napier grass silage had been postulated to be rather low, the timothy hay harvested at ripening stage was selected as a reference ration in this experiment. DM and $\mathrm{N}$ digestibilities of timothy hay are 53 and $51 \%$ at flowering and 47 and $40 \%$ at ripening stage
(AFFRC, 1987). Digestibilities of rice straw are $42 \%$ in DM and $26 \%$ in N (AFFRC, 1987). DM and $\mathrm{N}$ digestibilities of the timothy hay which was used in this experiment were 37.6 and $37.2 \%$, respectively, and they were lower than those at ripening stage. Comparing with timothy hay at heading stage, of which $\mathrm{DM}$ and $\mathrm{N}$ digestibilities are 60 and $65 \%$, respectively (AFFRC, 1987), DM digestibility of $65.0 \%$ of the napier grass silage was almost the same and $\mathrm{N}$ digestibility of $54.5 \%$ was lower a little, although both $\mathrm{DM}$ and $\mathrm{N}$ digestibilities of the napier grass silage were much higher than those of rice straw. Nitrogen retention was a little positive at the feeding of the napier grass silage, although negative at the timothy hay feeding. The same tendency was observed in body weight changes.

Characteristics of rumen fluid are shown in table 3. The $\mathrm{pH}$ value decreased with the feeding irrespective of rations. Total VFA concentration of rumen fluid taken before the morning feeding was a little higher in goats fed the napier grass silage than in those fed the timothy hay. The value increased after feeding of the silage but decreased by the hay feeding. These facts might be come from low digestibility of DM of the timothy hay and low energy supply to microorganisms which produce VFA in the rumen. Ammonia $\mathrm{N}$ concentration in the rumen fluid in goats fed the napier grass silage increased into $14 \mathrm{mg} / \mathrm{dl}$ after feeding, but that in goats fed the timothy hay was almost the same level irrespective

TABLE 2. DIGESTIBILITY OF DRY MATTER AND NITROGEN, AND NITROGEN BALANCE IN GOATS FED THE NAPIER GRASS SILAGE OR THE TIMOTHY HAY

\begin{tabular}{lcc}
\hline & \multicolumn{2}{c}{ Ration } \\
\cline { 2 - 3 } & Napier grass silage & Timothy hay \\
\hline DM intake (g/day) & $324 \pm 1^{1)}$ & $357 \pm 14$ \\
DM digestibility (\%) & $65.0 \pm 1.1^{* * * 2)}$ & $37.6 \pm 0.6$ \\
$\mathrm{~N}$ intake (g/day) & $4.66 \pm 0.09$ & $4.58 \pm 0.18$ \\
Fecal N excretion (g/day) & $2.12 \pm 0.04^{* *}$ & $2.87 \pm 0.11$ \\
$\mathrm{~N}$ digestibility (\%) & $54.5 \pm 1.0^{* *}$ & $37.2 \pm 0.1$ \\
Urinary N excretion (g/day) & $2.00 \pm 0.08^{*}$ & $2.63 \pm 0.18$ \\
Retained N (g/day) & $0.54 \pm 0.15^{* *}$ & $-0.92 \pm 0.14$ \\
Body weight changes (kg/day) & $0.03 \pm 0.03^{* *}$ & $-0.14 \pm 0.01$ \\
\hline
\end{tabular}

1) Mean \pm standard error of the mean $(n=3)$.

2) Statistical significant to the timothy hay;

$* * *: \mathrm{p}<0.001, * *: \mathrm{p}<0.01$ and $*: \mathrm{p}<0.05$. 


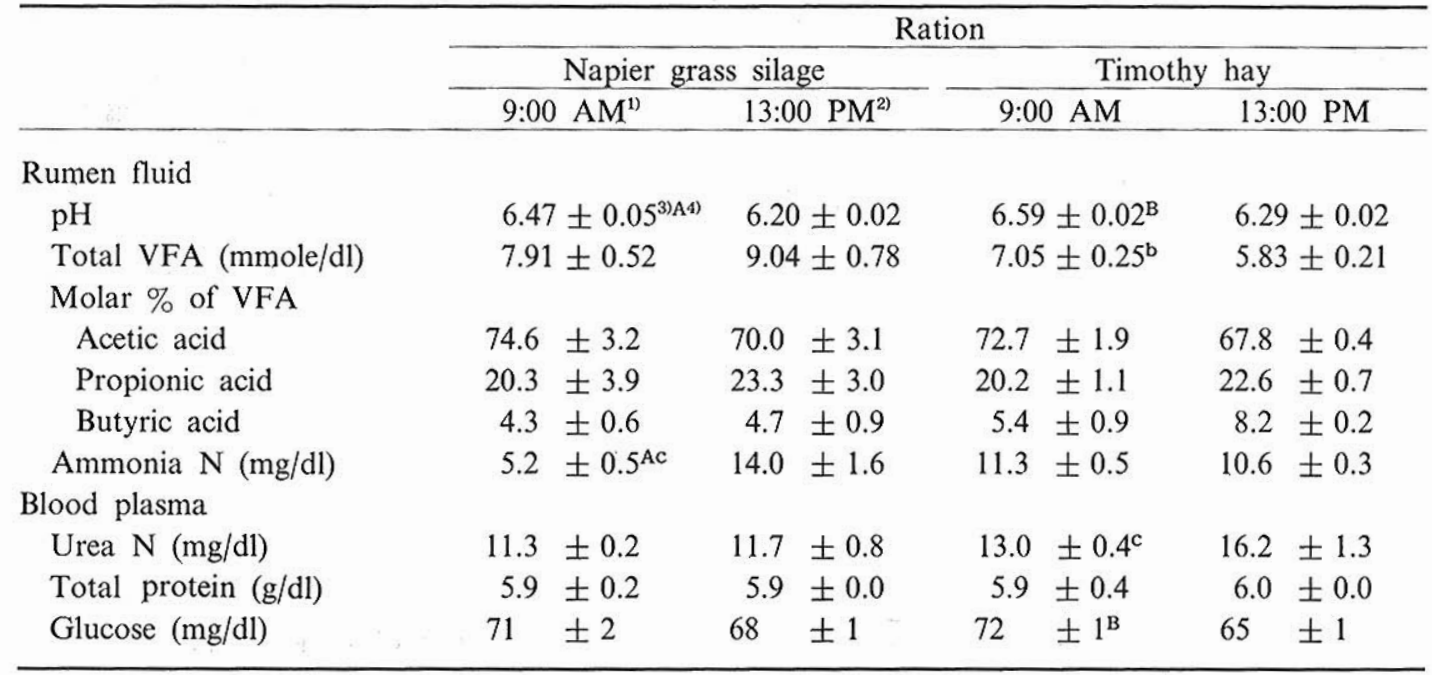

1) Just before the morning feeding.

2) 4 hours after the morning feeding.

${ }^{3)}$ Mean \pm standard error of the mean $(n=3)$.

4) Statistical significance:

A $(p<0.01)$ and a $(p<0.05)$; to the value at 13:00 PM of goats fed the napier grass silage, $B(p<0.01)$ and $\mathrm{b}(\mathrm{p}<0.05)$; to the value at 13:00 PM of goats fed the timothy hay, and $\mathrm{c}(\mathrm{p}<0.05)$; to the value at 9:00 AM of goats fed the timothy hay.

of feeding. Satter and Slyter (1974) suggested that 5 to $8 \mathrm{mg}$ ammonia $\mathrm{N} / \mathrm{dl}$ of rumen fluid was the optimum for maximum of the microbial growth. However, Krebs and Leng (1984) indicated that minimum ammonia $\mathrm{N}$ concentration for optimum intake of low digestibility forage was about $20 \mathrm{mg}$ ammonia $\mathrm{N} / \mathrm{dl}$. The difference in ammonia $\mathrm{N}$ concentration of the rumen fluid between the napier grass silage and the timothy hay feeding might affect digestibilities of the two forages.

Urea nitrogen, total protein and glucose concentrations in blood are also shown in table 3. Urea nitrogen in blood in goats fed the napier grass silage was almost constant, but these values in goats fed the timothy hay increased after feeding. These phenomena may be related to the increased urinary nitrogen excretion in goats fed the timothy hay, although digestibility of the timothy hay was lower than that of the napier grass silage. Hamada et al. (1968) suggested that a deficiency of energy supply induced the lower blood glucose concentration. Blood glucose concentration decreased from 72 to $65 \mathrm{mg} / \mathrm{dl}$ by the timothy hay feeding, while it remained at 68 $\mathrm{mg} / \mathrm{dl}$ when fed the napier grass silage. Even at the feeding of the napier grass silage energy supply to goats may be deficient a little.

As we wanted to know the digestibility of the napier grass silage itself in this experiment, goats were given only the napier grass silage with no supplementary concentrates. The napier grass silage used here were digested $65 \%$ by goats, and this value was almost equal to the mean level of the other forages. When napier grass harvested at appropriate interval was ensiled with molasses, the silage may have good chemical quality and digestibility.

\section{Acknowledgements}

The authors wish to thank Messrs. Y. Ito, T. Harata, M. Tsuge, T. Nagatomo and N. Inagaki for their technical assistance.

\section{Literature Cited}

AFFRC. 1987. Agriculture, Forestry and Fisheries Research Council Standard Tables of Feed Composition in Japan. Central Association of Livestock Industry, Tokyo. 


\section{NUTRITIVE VALUE OF NAPIER GRASS SILAGE}

Barnett, A. J. G. 1951. The colorimetric determination of lactic acid in silage. Biochem. J. 49:527-529.

Brown, D. L. and E. Chavalimu. 1985. Effects of ensiling or drying on five forage species in western Kenya: Zea mays (Maize stover), Pennisetum purpureum (Pakistan Napier grass), Pennisetum sp. (Bana grass), Impomea batata (Sweet potato vines) and Cajanus cajan (Pigeon pea leaves). Anim. Feed Sci. Technol. 13:1-6.

Catchpoole, V. R. and E. F. Henzell. 1971. Silage and silage making from tropical herbage species. Herbage Abstr. 41:213-221.

Hamada, T., S. Omori, K. Kameoka and H. Morimoto. 1968. Significance of blood glucose levels in early-weaned dairy calves. Bull. Nat. Inst. Anim. Ind. 18:1-6.

Henderson, A. R. and P. McDonald. 1975. The effect of delayed sealing on fermentation and losses during ensilage. J. Sci. Food Agric. 26:653667.

Krebs, G. and R. A. Leng. 1984. The effect of supplementation with molasses/urea blocks on ruminal digestion. Proc. Aust. Soc. Anim. Prod. 15:704.

McDonald, P., N. Henderson and S. Heron. 1991. The Biochemistry of Silage. 2nd ed., Chalcombe
Publications, Marlow, UK.

Miller, W. J., H. L. Dalton and J. K. Miller. 1961. Sudan grass silage at two stages of maturity versus rye grass and crimson clover with two filling procedures. J. Dairy Sci. 44:1921-1927.

National Research Council. 1981. Nutrient Requirements of Goats. National Academy Press. Washington D.C.

Panditharatne, S., V. G. Allen, J. P. Fontenot and M. C. N. Jayasuriya. 1986. Ensiling characteristics of tropical grasses as influenced by stage of growth, additives and chopping length. J. Anim. Sci. 63:197-207.

Satter, L. D. and L. L. Slyter. 1974. Effect of ammonia concentration on rumen microbial protein production in vitro. Br. J. Nutr. 32:199-208.

Yokota, H., T. Okajima and M. Ohshima. 1991. Effect of environmental temperature and supplementation of molasses on quality of napier grass (Pennisetum purpureum Schum.) silage. Asian-Australasian J. Anim. Sci. 4:377-382.

Woodard, K. R. and G. M. Prine. 1991. Forage yield and nutritive value of elephant grass as affected by harvest frequency and genotype. Agron. J. $83: 541-546$ 
